\title{
Seasonal activity and basking of the southernmost population of the freshwater turtle Phrynops hilarii (Chelidae)
}

\author{
María B. Semeñiuk ${ }^{1,2, *}$, Leandro Alcalde ${ }^{2,3}$
}

\begin{abstract}
This study focuses on basking behaviour of Phrynops hilarii in the southernmost population of the species' range. The objective was to determine how environmental features affect the basking behaviour of the species. We analyzed two years of data on the seasonal activity of the species for the same stream. We detected 389 P. hilarii basking, mostly alone (76.8\%), and on logs and branches (79.3\%), but large turtles used shorelines more frequently than did smaller turtles. Basking peaked during late winter and early spring. We found no correlation between the number of basking turtles and air, substrate or water temperatures. P. hilarii was active through all seasons, with activity peaking in summer, when temperature is highest but basking frequency is low. Type of substrate, time of day, and season are key factors that influence the basking behaviour of $P$. hilarii.
\end{abstract}

Keywords: Argentina, basking behaviour, short-necked chelid, South American turtles, substrates, temperatures.

\section{Introduction}

Basking is an important behaviour for most reptiles, which spend many hours exposed either to solar radiation or in contact with solarheated surfaces (Zug, Vitt and Caldwell, 2001). A key function of basking is thermoregulation, but drying of the skin and carapace is important in turtles (Boyer, 1965). Basking is related to and affected by factors such as nutritional status, acclimatisation, season, and gender of the individual (Hammond, Spotila and Standora, 1988).

Most of the studies about basking of freshwater turtles relate to emydid species from the Northern Hemisphere (Lindeman, 1999; Moore and Seigel, 2006; Peterman and Ryan, 2009; Selman and Qualls, 2011; Millar, Graham and Blouin-Demers, 2012; Umphrey et al., 2012;

1 - Museo de La Plata, Anexo Laboratorios, Sección Herpetología, Boulevard 120 y 62, CP 1900, La Plata, Buenos Aires, Argentina

2 - Consejo Nacional de Investigaciones Científicas y Técnicas, Av. Rivadavia 1917, C1033AAJ, CABA, Argentina

3 - Instituto de Limnología Dr. R. A. Ringuelet (CCT La Plata-CONICET), Boulevard 120 y 62, CP 1900, La Plata, Buenos Aires, Argentina

*Corresponding author;

e-mail: mbelen_semeniuk@fcnym.unlp.edu.ar
Lambert et al., 2013; Ryan et al., 2014; Nyhof and Trulio, 2015; Vignoli et al., 2015). Despite this geographical bias, some general conclusions may be drawn: (1) the turtle's habitat requires the presence of basking surfaces on which turtles can easily climb to warm themselves (Umphrey et al., 2012); (2) the type of substrate and substrate preference vary among species (Ryan et al., 2008; Peterman and Ryan, 2009) and in relation to turtle age; and (3) in some species, large turtles spend more time basking than do small turtles (Lefevre and Brooks, 1995; Selman and Qualls, 2011). Other aspects of basking remain poorly studied, such as the intra- and inter-specific interactions among basking turtles (Lovich, 1988) and how human activities affect basking (Nyhof and Trulio, 2015).

The stream at which we worked holds some of the most southerly populations of the longnecked chelid Hydromedusa tectifera, the shortnecked chelid Phrynops hilarii, and the emydid Trachemys dorbigni (Derocco, Alcalde and Rosset, 2005; Alcalde et al., 2012). These species make up one of the southernmost turtle communities in the world (Buhlmann et al., 2009), at the mouth of the Buñirigo stream on the Río de La Plata shoreline. 
Miscellaneous field observations (L. Alcalde) and captive-based experiences (Astor, 1983) suggest that $H$. tectifera practices sub-aquatic basking, as defined by Lacher, Alho and Pereira (1986): "employment of warmer surface water instead of substrates above the water surface", whereas $P$. hilarii basks out of the water (Richard, 1999). P. hilarii is the largest of these three species (up to about $5 \mathrm{~kg}$ body mass and $40 \mathrm{~cm}$ straight carapace length). Although common and widely distributed through southern Brazil, south-eastern Paraguay, Uruguay and north and central Argentina (Cabrera, 1998; Prado et al., 2012), there is still little field-based knowledge of the species.

This study explored basking behaviour of $P$. hilarii under natural conditions during one year, 2015. Our aim was to elucidate the relationship between basking and environmental features; consequently, we asked the following questions. 1) Do turtles show preference for specific substrate types when basking? 2) Is substrate type linked to turtle size? 3) How do air, water and substrate temperatures influence basking? In addition, we used trapping to assess the annual activity of this population of $P$. hilarii for two years, 2006-2008.

\section{Materials and methods}

\section{Study area}

Ten basking surveys were conducted from March 2015 to December 2015, each along a $3900 \mathrm{~m}$ meandering portion towards the mouth of the Buñirigo stream in the Río de La Plata shoreline (Magdalena, Buenos Aires Province, Argentina).

The section of the stream we sampled was influenced by the tidal regime of the Río de La Plata producing daily changes of water depth $(0.22 \mathrm{~m}$ to $1.47 \mathrm{~m}$ for the days we conducted the study). The tide level was obtained from the Naval Hydrographic Service. Stream margins are wellvegetated, with a mixed community of native (e.g., Celtis tala, Erythrina crista-galli, Sapium haematospermum, Salix humboldtiana, Schinus longifolius) and exotic (e.g., Populus alba, Morus sp., Ligustrum sp., Phoenix sp.) bushes and trees.

\section{Basking surveys}

Surveys were made by two surveyors using a two-person kayak, sampling the section from the mouth of the Buñirigo stream in the Río de la Plata upstream (10:30-13:00) and then downstream to the mouth (13:00-15:30). We recorded the following data: (1) species, number and size of turtles basking; (2) time of day; (3) substrate type; (4) wind speed both at the substrate on which turtles basked and at the middle of the stream (measured with a handheld anemometer Skywatch Atmos 991; accuracy $\pm 4 \%$ ); (5) water, air and substrate temperatures. Water temperature was measured in the middle of the stream (width mean: $8 \mathrm{~m}$ ) at $10 \mathrm{~cm}$ depth. We recorded air temperature at the same location as the water temperature but at one meter above the water surface. Substrate temperature was measured at the exact point the turtle was seen basking, utilizing a digital thermometer (Silcook; accuracy $\pm 1^{\circ} \mathrm{C}$ ). Substrates were classified as: (1) logs and branches; (2) dams of free-floating vegetation; and (3) shorelines (fig. 1). We distinguished a log from a branch based on their size: logs were wider and branches narrower than $20 \mathrm{~cm}$, respectively. Two relative turtle sizes (small $<200 \mathrm{~mm}$ and large $>200 \mathrm{~mm}$ ) were recognized by visual estimation using binoculars, because sometimes they dived in the water when the kayak approached. The time between turtle sighting and temperature recording never exceeded one or two minutes.

\section{Seasonal activity}

Data on captures were obtained once or twice per month between December 2006 and January 2008, employing two 1-mouthed, double-funnel beef-baited traps together with 8 fishing lines without hooks with 10 baits each (see Alcalde, Derocco and Rosset, 2010 for details) approximately $500 \mathrm{~m}$ upstream of the basking survey area. We completed 16 sample days, four in summer, five in autumn, three in spring and four in winter. Water temperatures were recorded twice each sample day, at mid-morning and early afternoon, in the middle of the stream at $10 \mathrm{~cm}$ depth.

\section{Data analysis}

Differences in how small and large turtles use different substrate types were analyzed using a two-way analysis of variance (ANOVA) combined with post hoc Tukey's test (Zar, 1999). Our ANOVA included one dependent variable (number of basking turtles) and two factors: turtle size class (small and large) and substrate type (log-branch, shoreline and dam). Data were fourth-root transformed to fulfil the assumptions of the test.

The water, air and substrate temperature variations among surveys were evaluated using the non-parametric version of the one-way ANOVA (Kruskall-Wallis test) combined with post hoc tests (Dunn's procedure). We employed the Bonferroni correction in order to be more conservative when many pairwise comparisons are conducted (Dytham, 2011). Temperature data and basking surveys we obtained during 2015 were used to evaluate the relationship between number of basking turtles with water, air and substrate temperatures, using Spearman rank correlations. We excluded wind speed at the basking substrate and middle of the stream from the analysis because there was little difference $(\leqslant 4 \mathrm{~km} / \mathrm{h})$ across surveys. 


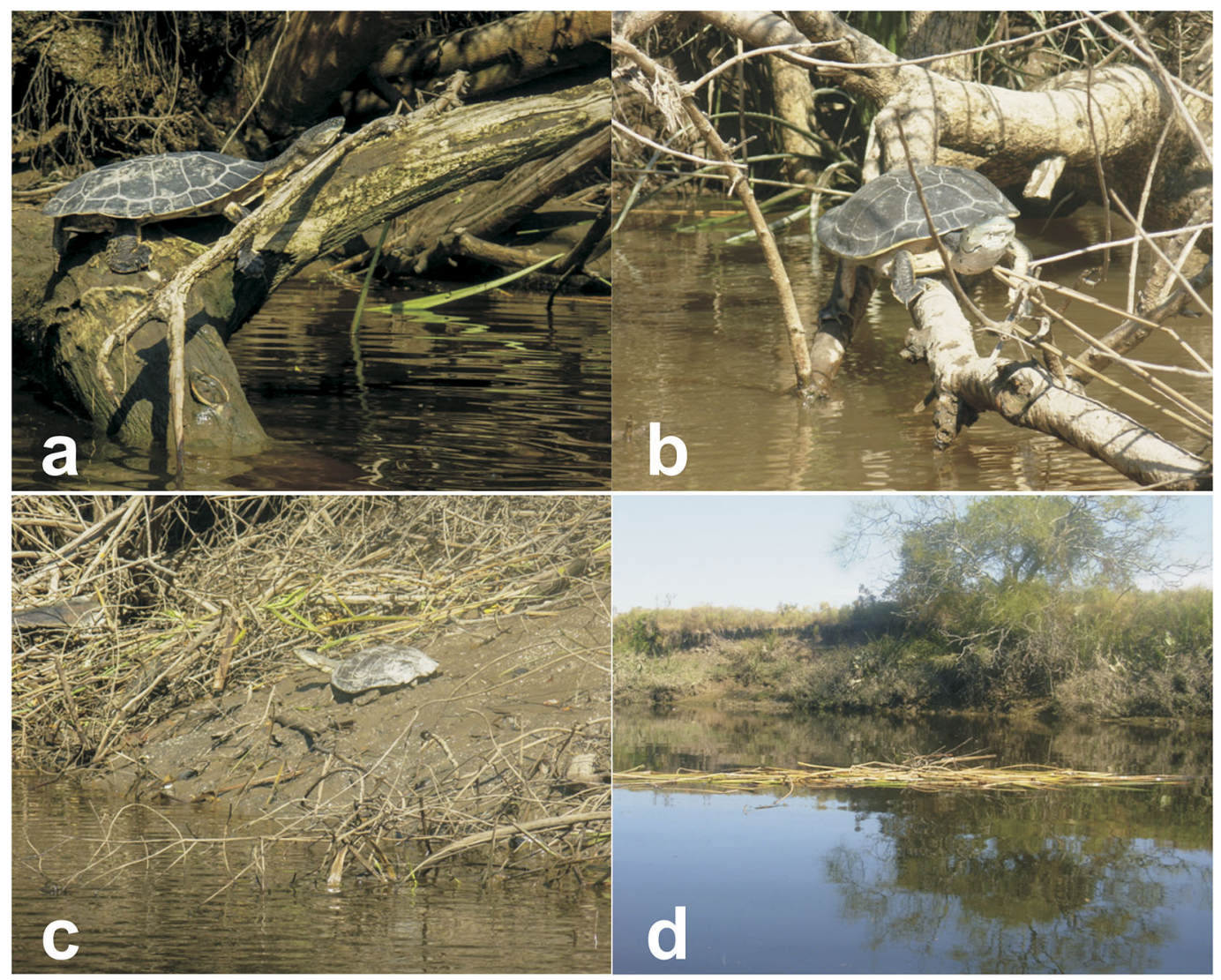

Figure 1. Examples illustrating the four types of substrate we identified for the present study. (a) $\operatorname{Logs}(>20 \mathrm{~cm}$ wide) and (b) branches ( $<20 \mathrm{~cm}$ wide) of the native tree Salix humboldtiana; (c) shorelines; (d) dams.

The annual activity cycle of the species was inferred from the number of turtles trapped between 2006 and 2008, and correlated with the water temperatures of the same period. Months of the captures were combined into seasons in order to better evaluate seasonal differences. All analyses were made using the software Xlstat Pro Version 7.5 and free trial of Xlstat-Premium (Addinsoft SARL, Paris, France); $P$ value was considered significant when $<0.05$.

\section{Results}

We found 389 Phrynops hilarii individuals basking (mean $\pm \mathrm{SD}=38.9 \pm 39.2$ individuals/survey; $n=10$ ). Most observations (76.8 \pm $12.9 \%$ ) were of turtles basking alone but in a single instance, we found up to 24 individuals basking on a tree log. We recorded 304 large and 85 small basking turtles. We detected a few other species that were not included in the analysis. These records included three native sliders
Trachemys dorbigni basking alone on shorelines (two cases) or on submerged logs (one case). In addition, the species and size of six basking turtles could not be assessed, and three $P$. hilarii were detected floating freely and exposing the dorsum of the carapace to air.

We observed turtles basking on $\operatorname{logs}$ and branches, dams, and shorelines (fig. 1). Logs and branches, mainly of the native tree Salix humboldtiana $(33.8 \%)$ and of the exotic tree Populus alba (26.9\%), constituted the bulk of the observations $(79.3 \%)$ regardless of the size of the turtles (fig. 2). The ANOVA showed interaction between turtle size class and substrate type (interaction: $F_{2,54}=5.221, P<0.01$ ). The post hoc tests revealed that (1) both size classes used log-branches more frequently than dams (large $P<0.001$; small $P<0.05$ ); (2) small 


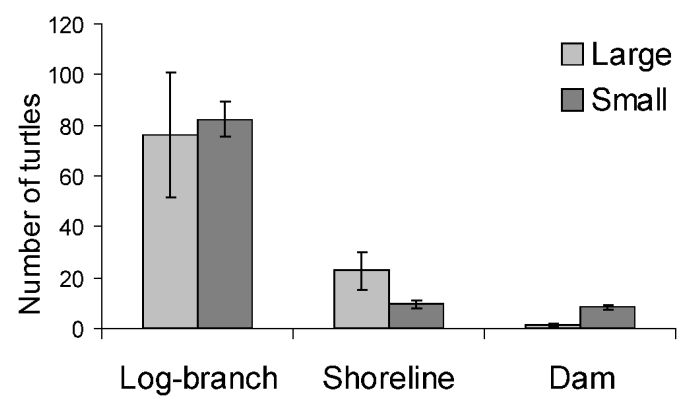

Figure 2. Number (mean and standard deviation) of large and small turtles we observed basking on each substrate type across ten basking surveys $(n=10)$ conducted during the year 2015. As we did for all statistical analyses, turtles basking on logs and branches were lumped into a single category (Log-branch).

turtles basked more frequently on log-branches than on shorelines $(P<0.05)$; (3) large turtles used shorelines more than dams $(P<0.001)$, and more than small turtles $(P<0.01)$. The average temperature of shorelines was higher $\left(25.8^{\circ} \mathrm{C} \pm 4.5\right)$ than those of $\operatorname{logs}$ and branches $\left(23.7^{\circ} \mathrm{C} \pm 3.9\right)\left(\mathrm{t}\right.$-test: $t_{348}=4.004, P<$ $0.0001)$.

With respect to the time of day when turtles bask, most $(60.7 \%)$ were seen between late morning and midday (10:30-13:00 $\mathrm{h}$ ) and the remainder between 13:00 and 15:30 $\mathrm{h}$.

Seasonally, the number of basking turtles in each survey indicates that the peak of basking activity occurred between late winter and early spring (August, September and October) (fig. 3), not coincident with the highest water or air temperatures (fig. 3), which were recorded in December (early summer). More specifically, the greatest number of basking turtles was recorded in October (fig. 3) when temperatures were lower $\left(t_{\text {Substrate49 }}=-2.187, P=0.034\right.$, $t_{\text {Water49 }}=-18.362, P<0.0001$, and $t_{\text {Air49 }}=$ $-5.425, P<0.0001)$ than those recorded during December. Substrate average temperatures were higher than those of water and air $\left(t_{756}=18.726, P<0.0001\right.$, and $t_{756}=8.341$, $P<0.0001$, respectively). Basking frequency was low on days when water temperatures did not reach $15^{\circ} \mathrm{C}$ (early winter, June: $12.2-12.5^{\circ} \mathrm{C}$, two basking turtles) or exceeded $25^{\circ} \mathrm{C}$ (early

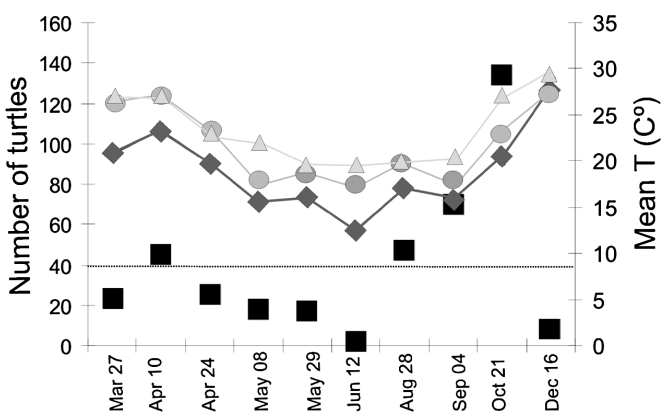

Figure 3. Number of basking turtles (black squares) plotted versus mean water (diamond shape), air (circles) and substrate (triangles) temperatures we obtained during the year 2015. The dotted black line shows the mean number of basking turtles.

summer, December: $26 \cdot 2-30^{\circ} \mathrm{C}$, eight basking turtles) (fig. 3).

Comparisons among water (Kruskal-Wallis Test: $H=329.126)$, air $(H=315.609)$, and substrate $(H=236.441)$ temperatures show significant variation $(\mathrm{df}=8, P<0.0001$ ) across months. Although these temperatures did not vary significantly between autumn (May) and winter surveys (August, September) (substrate: $P=0.779$ and $P=0.482$; air: $P=$ 0.310 and $P=0.368$; water: $P=0.085$ and $P=0.896$, respectively), the number of turtles we recorded in winter was higher (fig. 3) than those found during autumn.

Finally, there was no correlation between the number of basking turtles and the mean water, air and substrate temperatures we recorded during each survey: water (Spearman rank correlation: $\rho=0.176, P=0.627)$, air $(\rho=0.067$, $P=0.855)$, and substrate $(\rho=0.158, P=$ $0.663)$.

The analysis of the turtles we trapped between 2006 and 2008 indicates the species is active throughout the year except when the water temperature is below $10^{\circ} \mathrm{C}$. We found significant differences between winter and summer $(U=19.500, P=0.017)$ in the number of trapped turtles, with a peak of captures in summer months. In fact, the amount of small $(<200 \mathrm{~mm})$ and large $(>200 \mathrm{~mm})$ turtles we trapped during this period correlates positively with water temperature $(\rho=0.805, P<$ 

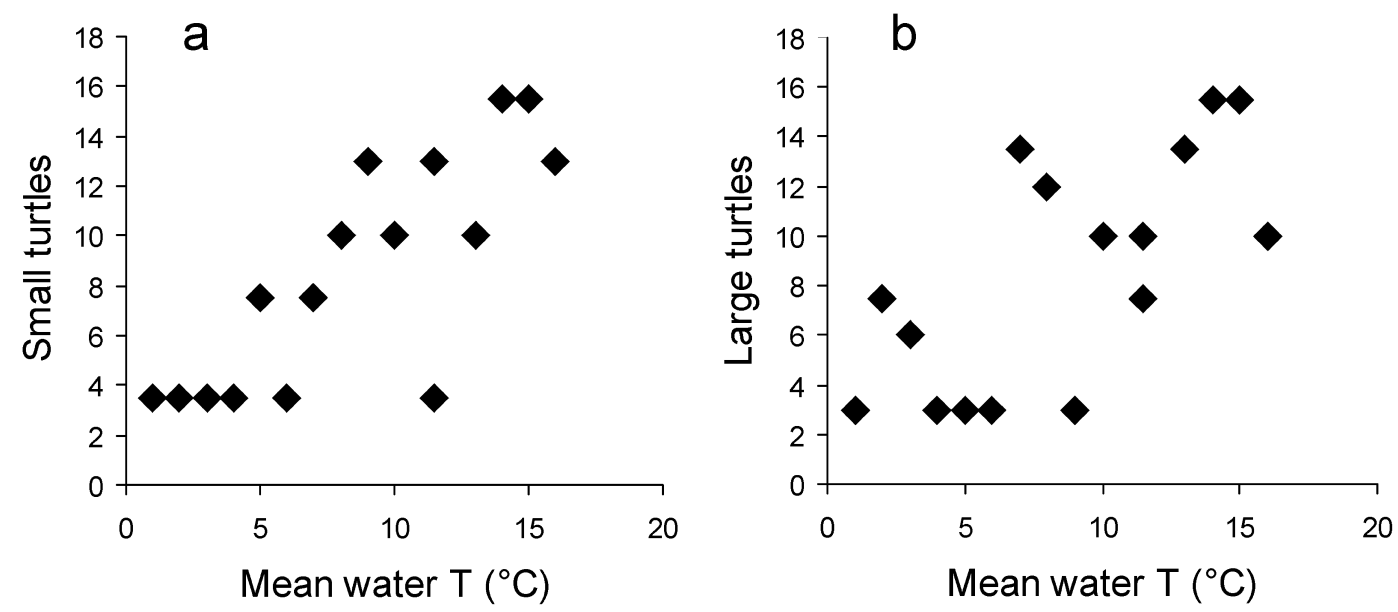

Figure 4. Scatter plot of Spearman correlation values for number of small (a) and large (b) turtles we trapped at Buñirigo stream between December 2006 and January 2008 and mean water temperatures $\left({ }^{\circ} \mathrm{C}\right)$ from the same period. Note the positive correlation between the two variables.

0.0001 and $\rho=0.687, P<0.005$, respectively; fig. 4).

\section{Discussion}

\section{Substrates}

The present study reveals that most $P$. hilarii bask on logs and branches instead of on stream margins or dams. There is considerable published evidence about substrates utilized by freshwater turtles, e.g. the Common Map Turtle (Graptemys geographica) prefers to bask on rock-covered banks (Peterman and Ryan, 2009) whereas emergent deadwood is the preferred substrate of Red-eared Sliders (Trachemys scripta elegans) and Painted Turtles (Chrysemys picta) (Ryan et al., 2008). The present study also shows that large individuals of $P$. hilarii use shorelines more than smaller turtles. Such biases towards certain substrates were reported in an early work by Selman and Qualls (2011), who reported sex and age biases towards certain substrates in the Yellow-blotched Sawback (Graptemys flavimaculata).

Substrate temperatures were the warmest of the three substrate types examined. Boyer (1965) demonstrated that the temperature of a basking turtle is affected by (1) the thermal conductivity of the substrate and (2) the closeness of the contact with the turtle basking on it. We agree with this but an additional question remains unexplained: why do small $P$. hilarii use shorelines infrequently as basking sites if this substrate provides the best thermal environment? A possible explanation may be that stream margins are less safe substrates for small turtles than dams or tree logs. A small turtle basking on the shoreline is probably an easy prey for a terrestrial predator, for the size of the turtle itself and because shorelines have a longer escape distance to the water than that from logs and dams.

\section{Sociality}

Another point to be highlighted concerns the lack of gregariousness of the species in the population studied here. In fact, most $P$. hilarii individuals we observed were basking alone. Solitary basking also was reported for North American emydids, i.e. Pseudemys texana, Graptemys pseudogeographica, Trachemys scripta, and trionychids, i.e. Apalone mutica and A. spinifera (Hill and Vodopich, 2013). Observations made by Richard (1999) on a nonnatural population of $P$. hilarii, inhabiting a network of artificial lagoons dotted with a few basking sites, indicate a high tolerance of these 
turtles to bask together. In contrast, our study shows that, under natural conditions and with high basking substrate availability, as occurs in the sampled section of the Buñirigo stream, the study species usually basks alone.

Our results indicate that most individuals bask between late morning and midday (10:3013:00) instead in the early afternoon (13:0015:00). A study on the North American emydids Chrysemys picta marginata, G. geographica, and T. scripta indicates two peaks of basking, one during the morning and the other in the early afternoon (Peterman and Ryan, 2009). Instead, the North American emydid C. picta bellii displays more basking events during the morning (Umphrey et al., 2012), as does the European emydid Emys orbicularis (Cadi and Joly, 2003). Such studies indicate that these northern hemisphere emydids avoid basking during the hours of most intense solar radiation.

\section{Interaction of effects}

This study shows that type of substrate, time of day, and season of the year are three key factors that combine to influence basking behaviour of Phrynops hilarii. But specifically, how do air, water and substrate temperatures interrelate to influence basking? It seems a pivotal question to be solved in order to achieve a better understanding of the species' behavioural responses under different environmental conditions. Coleman and Gutberlet (2008) demonstrated that body temperature and preferred basking temperature vary in relation to the biological requirements of each turtle species. Thus, both daily and seasonal variations in basking features may occur at the species level and among different species.

In agreement with early works (Lefevre and Brooks, 1995; Coleman and Gutberlet, 2008), seasonal differences in basking in $P$. hilarii show a clear peak of basking activity during late winter and early spring but not in early summer when the temperature is higher.

Our monthly data on captures covering all seasons indicate a high activity peak during summer months, substantially higher than in winter but not significantly different from spring and autumn months. Thus, this species is active all the year within a certain range of temperatures. Environmental temperatures and basking frequency are not always correlated throughout the year in this species. Our trapping and basking survey data indicate that the species is very active when the temperature is very high, times at which basking frequency appears low. Our basking surveys indicated that $P$. hilarii varies basking frequency among seasons. But, as we conducted basking surveys between 10:30 $\mathrm{h}$ and $15: 30 \mathrm{~h}$, an alternative explanation may be that $P$. hilarii displaces the basking events towards very early morning and very late afternoon in order to avoid the moments of greatest solar radiation. Other species show a correlation between a range of air temperature and basking frequency, as in the case of the North American emydids, Graptemys ouachitensis sabinensis and G. pseudogeographica kohnii, which show a clear-cut basking peak at water temperatures between $15-25^{\circ} \mathrm{C}$ (Coleman and Gutberlet, 2008).

The experiments of Monteiro and Diefenbach (1987), indicated that the preferred body temperatures of $P$. hilarii were $32.6^{\circ} \mathrm{C}$ for postfeeding and $29.3^{\circ} \mathrm{C}$ during long fasting periods. Other authors have proposed explanations for the low basking frequency during summer: (1) in summer, turtles reach their optimal body temperature more quickly than in the rest of the year (Lefevre and Brooks, 1995; Ben-Ezra, Bulté and Blouin-Demers, 2008); (2) in summer, the water temperature alone can satisfy the heat requirements of turtles, and thus they alternate between underwater and aerial basking, with the advantage of decreasing the risk of predation (Boyer, 1965; Chessman, 1987; Picard, Carrière and Blouin-Demers, 2011; Shen et al., 2013; Feaga and Haas, 2015). We agree with such explanations, since they seem consistent with the requirements of this species: turtles 
bask to increase their body temperature and require longer basking time when conditions are cool than during summer.

Other authors (Polo-Cavia, López and Martín, 2012) proposed an alternative explanation for the very low basking activity during winter months. They thought that low basking activity may be caused by low food intake during winter, which reverses in spring leading to a high basking frequency due to metabolic demands; this aspect is also highlighted by Coleman and Gutberlet (2008). However, prey availability seems not to constrain the activity level or basking behaviour in the studied population of $P$. hilarii. Prey items are available throughout the year in the Buñirigo stream with variations in prey composition but not in prey abundance (see Alcalde, Derocco and Rosset, 2010). It is possible that turtles decrease their metabolism gradually as both photoperiod and temperature decrease. In this case, turtles would reduce food intake and basking activities as a response instead of as a cause. In fact, our data on captures of $P$. hilarii throughout a whole year, together with data on prey availability and feeding information on the species from Alcalde, Derocco and Rosset (2010), demonstrate that neither activity nor food intake cease in the coldest months.

Although far from all-encompassing, some of the topics highlighted here constitute a first step to understanding the habitat requirements (substrate types, basking seasonality with no strict link to high temperatures) and lack of gregariousness of $P$. hilarii.

Acknowledgements. The present work constitutes the Scientific Contribution $N^{\circ} 990$ of the Instituto de Limnología Dr. R.A. Ringuelet. Authors acknowledge the continuous support of CONICET and UNLP. We thank the Ministerio de Asuntos Agrarios of Buenos Aires province for permissions (permits $\mathrm{N}^{\circ} 102 / 2014-025$ and 69/2016), and Ayelen Lutz who provided the portable weather station used for the present study. Anonymous reviewers and Joss Heywood have greatly improved the contents and the English language of this version of the manuscript, and we are grateful to them.

\section{References}

Akins, C.D., Ruder, C.D., Price, S.J., Harden, L.A., Gibbons, J.W., Dorcas, M.E. (2014): Factors affecting temperature variation and habitat use in free-ranging diamondback terrapins. J. Therm. Biol. 44: 63-69.

Alcalde, L., Derocco, N.N., Rosset, S.D. (2010): Feeding in syntopy: diet of Hydromedusa tectifera and Phrynops hilarii (Chelidae). Chelonian Conserv. Biol. 9: 33-44.

Alcalde, L., Derocco, N.N., Rosset, S.D., Williams, J.D. (2012): Southernmost localities of Trachemys dorbigni and first record of Trachemys scripta elegans for Argentina (Cryptodira: Emydidae). Chelonian Conserv. Biol. 11: 128-133.

Astor, E.D. (1983): Observaciones sobre el comportamiento estacional de Hydromedusa tectifera Cope, Phrynops hilarii (Dum. y Bib.) y Platemys spixii Dum. y Bib. en cautiverio (Testudines: Chelidae). Bol. Asoc. Herpetol. Arg. 1: 8 .

Ben-Ezra, E., Bulté, G., Blouin-Demers, G. (2008): Are locomotor performances co-adapted to preferred basking temperature in the northern map turtle (Graptemys geographica)? J. Herpetol. 42: 322-331.

Boyer, D.R. (1965): Ecology of the basking habit in turtles. Ecology 46: 99-118.

Buhlmann, K.A., Akre, T.S.B., Iverson, J.B., Karapatakis, D., Mittermeier, R.A., Georges, A., Rhodin, A.G.J., van Dijk, P.P., Gibbons, J.W. (2009): A global analysis of tortoise and freshwater turtle distributions with identification of priority conservation areas. Chelonian Conserv. Biol. 8: 116-149.

Cabrera, M.R. (1998): Las tortugas continentales de Sudamérica austral. Córdoba, Ed. M. Cabrera.

Cadi, A., Joly, P. (2003): Competition for basking places between the endangered European pond turtle (Emys orbicularis galloitalica) and the introduced red-eared slider (Trachemys scripta elegans). Can. J. Zool. 81: 1392-1398.

Chessman, B.C. (1987): Atmospheric and aquatic basking of the Australian freshwater turtle Emydura macquarii (Gray) (Testudines: Chelidae). Herpetologica 43: 301306.

Coleman, J.L., Gutberlet, R.L. (2008): Seasonal variation in basking in two syntopic species of map turtles (Emydidae: Graptemys). Chelonian Conserv. Biol. 7: 276-281.

Derocco, N.N., Alcalde, L., Rosset, S.D. (2005): Ampliación de la distribución de Phrynops hilarii (Pleurodira: Chelidae) en Argentina. Cuad. Herpetol. 19: 63.

Dytham, C. (2011): Choosing and Using Statistics: a Biologist's Guide, 3rd Edition. Wiley-Blackwell, Oxford.

Feaga, J.B., Haas, C.A. (2015): Seasonal thermal ecology of bog turtles (Glyptemys muhlenbergii) in Southwestern Virginia. J. Herpetol. 49: 264-275.

Hammond, K.A., Spotila, J.R., Standora, E.A. (1988): Basking behavior of the turtle Pseudemys scripta: effects of digestive state, acclimation temperature, sex, and season. Physiol. Zool. 61: 69-77.

Harden, L.A., Pittman, S.E., Gibbons, J.W., Dorcas, M.E. (2009): Development of a rapid-assessment technique for diamondback terrapin (Malaclemys terrapin) populations using head-count surveys. Appl. Herpetol. 6: 237-245. 
Hill, S.K., Vodopich, D.S. (2013): Habitat use and basking behavior of a freshwater turtle community along an urban gradient. Chelonian Conserv. Biol. 12: 275-282.

Lacher, T.E., Alho, C.J.R., Pereira, I.G.T. (1986): The relation between cloacal temperature and ambient in five species of Brazilian turtles. Rev. Bras. Biol. 46: 563566.

Lambert, M.R., Nielsen, S.N., Wright, A.N., Thomson, R.C., Shaffer, H.B. (2013): Habitat features determine the basking distribution of introduced red-eared sliders and native western pond turtles. Chelonian Conserv. Biol. 12: 192-199.

Lefevre, K., Brooks, R.J. (1995): Effects of sex and body size on basking behavior in a Northern population of the painted turtle, Chrysemys picta. Herpetologica 51: 217 224.

Lindeman, P.V. (1999): Surveys of basking map turtles Graptemys spp. in three river drainages and the importance of deadwood abundance. Biol. Conserv. 88: 33 42.

Lovich, J. (1988): Aggressive basking behavior in eastern painted turtles (Chrysemys picta picta). Herpetologica 44: 197-202.

Millar, C.S., Graham, J.P., Blouin-Demers, G. (2012): The effects of sex and season on patterns of thermoregulation in Blanding's turtles (Emydoidea blandingii) in Ontario, Canada. Chelonian Conserv. Biol. 11: 24-32.

Monteiro, L.P., Diefenbach, C.O.D.C. (1987): Thermal regime of phrynops hilarii Reptilia Chelonia. Bol. Fisiol. Anim. 11: 41-50.

Moore, M.J.C., Seigel, R.A. (2006): No place to nest or bask: effects of human disturbance on the nesting and basking habits of yellow-blotched map turtles (Graptemys flavimaculata). Biol. Conserv. 130: 386-393.

Nyhof, P.E., Trulio, L. (2015): Basking Western pond turtle response to recreational trail use in urban California. Chelonian Conserv. Biol. 14: 182-184.

Peterman, W.E., Ryan, T.J. (2009): Basking behavior of emydid turtles (Chysemys picta marginata, Graptemys geographica, and Trachemys scripta elegans) in an urban landscape. Northeast. Nat. 16: 629-636.

Picard, G., Carrière, M.-A., Blouin-Demers, G. (2011): Common musk turtles (Sternotherus odoratus) select habitats of high thermal quality at the northern extreme of their range. Amphibia-Reptilia 32: 83-92.

Polo-Cavia, N., López, P., Martín, J. (2012): Feeding status and basking requirements of freshwater turtles in an invasion context. Physiol. Behav. 105: 1208-1213.
Prado, W.S., Waller, T., Albareda, D.A., Cabrera, M.R., Etchepare, E., Giraudo, A.R., González Carman, V., Prosdocimi, L., Richard, E. (2012): Categorización del estado de conservación de las tortugas de la República Argentina. Cuad. Herpetol. 26: 375-388.

Richard, E. (1999): Tortugas de las regiones áridas de Argentina: Contribución al conocimiento de las tortugas de las regiones áridas de Argentina (Chelidae y Testudinidae) con especial referencia a los aspectos etoecológicos, comerciales y antropológicos de las especies del complejo chilensis (Chelonoidis chilensis y Ch. donosobarrosi) en la provincia de Mendoza. Bs. As, L.O.L.A.

Ryan, T.J., Conner, C.A., Douthitt, B.A., Sterrell, S.A., Salsbury, C.M. (2008): Movement and habitat use of two aquatic turtles (Graptemys geographica and Trachemys scripta) in an urban landscape. Urban Ecosystems 2: 213-225.

Ryan, T.J., Peterman, W.A., Stephens, J.D., Sterrett, S.C. (2014): Movement and habitat use of the snapping turtle in an urban landscape. Urban Ecosystems 17: 613-623.

Selman, W., Qualls, C.P. (2011): Basking ecology of the yellow-blotched sawback (Graptemys flavimaculata), an imperiled turtle species of the Pascagoula River system, Mississippi, United States. Chelonian Conserv. Biol. 10: 188-197.

Shen, J., Meng, F., Zhang, Y., Du, W. (2013): Field body temperature and thermal preference of the big-headed turtle Platysternon megacephalum. Curr Zool 59: 626632.

Umphrey, A., Kletchko, A., Desrosiers, D., Burgess, M. (2012): Basking Preferences and Interspecies Interactions of the Western Painted Turtle (Chrysemys picta bellii) at Swan Lake, Victoria, BC. Camosun College Environmental Technology Department, Victoria.

Vignoli, L., Bologna, M.A., Manzini, S., Rugiero, L., Luiselli, L. (2015): Attributes of basking sites of the European pond turtle (Emys orbicularis) in central Italy. Amphibia-Reptilia 36: 125-131.

Zar, J.H. (1999): Biostatistical Analysis, 4th Edition. Prentice Hall, Upper Saddle River.

Zug, G.R., Vitt, L.J., Caldwell, J.P. (2001): Herpetology: an Introductory Biology of Amphibians and Reptiles, 2nd Edition. Academic Press, San Diego.

Submitted: September 6, 2016. Final revision received: February 9, 2017. Accepted: February 12, 2017.

Associate Editor: Uwe Fritz. 